\title{
Enlighment Strategy Leads To A Quality Learning At Islamic School In 4.0 Era
}

\author{
Mukhamad Musyafiudin', Ahmadi Ahmadi² \\ \{Syf18udn@gmail.com¹, Ahmadi@iainponorogo.ac.id ${ }^{2}$ \} \\ ${ }^{1,2}$ Faculty of Tarbiyah and Teacher Training, The State Institute of Islamic Studies Ponorogo \\ Indonesia
}

\begin{abstract}
Strategic management can move learning organizations to achieve a harmony at various levels. The article intends to elaborate on three levels of learning; (i) leaders, (ii) education staff, (iii) and teachers-learners. The researchers used a qualitative approach to elaborate the focuses. The result is; i) the leadership activities based on strategic issues of locality to face the revolutionary era as strategic work plans, ii) business curricula was compiled according to special specifications for sharpening student expertise, iii) the implementation of learning strategies were realized by paying an attention to the program's distinction for gaining a higher-order thinking skills for facing 4.0 era. Finally, they recommended the usage of it.
\end{abstract}

Keywords: Strategic, quality and learning.

\section{Introduction}

Improving the quality of learning is not a simple job because it requires planning, realizing and continuing the real action especially with the start of the 4.0 industrial revolution era. In this era, emerging technologies such as artificial intelligence will shift more of the role of humans. This has to inspire us to prepare mentally and skills that have competitive advantage. One of the main steps to preparing skills is behavioral attitude, improving selfcompetence and having a spirit of literacy [1]. Therefore, educational institutions are expected to be able to prepare the next generation that have high quality human resources for the glory of the nation.

Stainer dan Miner said that strategy refers to the formulation of basic organizational missions, purposes and objectives, policy and program strategies. They can be understood simply that strategic planning is a plan that concerns the future success of an organization. Strategic planning as well as a means that helps provides guidance for leaders in achieving organizational vision, mission and objectives. So, Strategic planning is one formation of strategy included in the perspective of rational based strategy. This strategy is suitable to use if the situation is stable, environmental changes can be anticipated, the pressure of change is weak and competition is still limited, so the concentration of institutions rests on long-term goal achievement [2]. The use of strategic planning in education is relevant as long as educational institutions receive support from the government. So, that despite the turmoil of environmental changes but most of the institutions can still be anticipated by educational institutions. 
The State of Islamic high school (MAN) 2 Madiun Indonesia has used a strategic planning in the Islamic high school work plan in improving the quality of education. This is used as a reference for working or a guide for all activities, including learning activities. The process of preparing was preceded by Islamic school self evaluation to see various potentials and abilities of themselves through SWOT analysis. Therefore, the purpose of this study is to reveal more deeply about 3 things, namely: (i) strategic activities carried out by the headmaster in improving the quality of learning, (ii) strategic activities carried out by curriculum workers in improving the quality of learning, (iii) strategic activities carried out by teachers in improving the quality of learning in MAN 2 Madiun Indonesia.

\section{Strategic Planning In Learning Orientation}

There are some theories regarding the steps taken in strategic planning. Strategic planning began to be applied in the new education world two decades ago, when educational institutions are forced to deal with various changes and must be responsive to challenges that arise within and outside the institution's environment. Then, finally an educational institution began to use strategic planning as a tool to achieve benefits the environmental changing [3].

Implementation of strategy is the most decisive step in management strategy. By implementation can be known both the effects and the benefits of the formulation of strategies that have been prepared before [4]. It happens because no matter how good a plan will be without implementation or action. Implementation of the strategy is more oriented to the formation of culture, the creation of effective organizational structures, financing, development of information systems and employing relations with organizational performance. Generally, there are four levels of strategy, there are; i) enterprise strategy, a strategy that communicates the organization with the demands of the community, ii) corporate strategy, a strategy at the leadership level to effectively steps of achieving the organization's main mission, iii.) strategy business unit is a strategy at the production unit level to lure customers iv) functional strategy, a strategy that is applied at the level of technical implementation area [5].

According to the National Education System Law is the process of interaction of students with educators and learning resources in a learning environment [6], and the quality is something that satisfies and exceeds the customer's request and needs [7]. Based on this theory, it is known that the quality of learning means the implementation of a series of learning processes that are able to meet or exceed the expectations of education's customers. One approach that can be used to determine the quality of the education process is the system approach. That cause the system is a unit of components that interact and are interrelated with each other to achieve an expected result optimally based on the intended purpose [8].

To strengthen the system, we need a strategic way of thinking and acting on every line. According to Bryson, there are several steps in strategic planning; i) initiating and agreeing on the strategic planning process, ii) clarifying the mandate and mission organization, iii) assessing SWOT approach for identifying strategic issues facing the organization, v) formulating strategies to manage issues, vi) creating effective organizational visions in the future.[9]

At Islamic school, the quality of learning is achieved from the top to the bottom. It starts with the preparation of a corporate strategy strategic plan outlined by the Head of Islamic School has formed an Islamic school work plan, Strategy Business Unit has constructed a school based curriculum. At last, functional strategy level where teaching learning instrument are made by the teachers including the preparation of syllabus, learning Implementation plans. 


\section{Research Methods}

This used qualitative approach that used a descriptive data as research procedure in the form of words written and the behavior of the people observed [10]. So, the source and type of data in this study are: words, actions, written sources, photos, statistics, recordings and etc. The steps of those has been conducted as follows; i) the words of the people interviewed or informants, namely about the application of strategic planning related to improving the quality of learning, starting from the level of headmaster, curriculum affair, teacher and student, ii) the actions of observing people in implementing the strategy to improve the quality of learning, iii) written sources in the formation of Islamic school documents relating to organizational strategic management such as: Islamic school work plan, curriculum of Islamic school Aliyah Negeri 2 Madiun, vision, mission and organizational goals, organizational structure, iv) the photo as a reinforcement of the results of observation, statistical data such as data on the number of teaching staff and education, the number of graduates, institutional achievements, and the number of students, vi) the type of interview used in this study used is semistructured interviews. Documentation is a document about the profile of the Islamic School, as well as various written policies from the head of the Islamic School in the Islamic school Work Plan as well as policies from the Curriculum development contained in the Islamic school Curriculum, as well as the policies of the teacher contained in learning devices, and photos activities at the Islamic School.

Data analysis is done by organizing data[11]. Data analysis in a single social situation is a data analysis carried out in each research location by using interactive data analysis. Triangulation technique is a technique of checking the validity of data that uses something else outside the data for checking purposes or as a comparison to that data. In this context of study, the triangulation technique used two techniques, sourced triangulation and method triangulation.

\section{Findings}

\section{Strategic Activites at several Levels}

\section{a. Leaders}

Becoming an accomplished, disciplined, Islamic cultured based on faith and piety, formatted vision and objective conditions of the Islamic School, the headmaster motivates various policies related with preparing strategic planning in the formation of an Islamic school work plan. The point is as a guideline in taking policies, implementing learning programs and administration of other Islamic schools. The stakeholder prepares the person in charging of each program and issues for them. Then, all programs can be carried out regularly. By the organization going on, it indicates that strategic planning has been implemented. [12].

\section{b. Curriculum Department}

In improving the quality of learning, it can be seen from the 7 steps of developing curriculum as following; i) diagnosis of needs, the main needs of society are in the fields of Mathematics and Natural Sciences, Social Sciences, Religion, the need for information technology, ii) Formulating of objective, the aim of the Islamic school is to serve the community by organizing various types of learning because the average student will continue to university, iii) Selecting of content, teachers may develop according to their 
respective characteristics. The specialization groups of Social Sciences, Mathematics and Natural Sciences, Religious Sciences, are also materials in the automotive, fashion, electrical, sports, arts and etc, iv) organizing the content, those are refers to the implementation of the 2013 curriculum after which the curriculum examines it. It also collects and views the contents of the teacher learning device while ratifying the authority of the stakeholder, v) choosing a learning experience, both teachers and leaners have to maintain a balance of cognitive aspects with others. It also the formation of characters through the habit of reading the Quran before the lesson begins, vi) organizing learning experiences, it's based on specialization and characteristics of each student for class entry requirements model through IQ test with a score must be above 130, the curriculum related to Olympic material, the study time are given additional material in mathematics, physics, chemistry, biology, economics. There is also a CI (Smart Special) class that is taken within two years. Then there is the BI class (Special Talent) to hone non-academic achievements in sports and arts, there is also a skills program, vii) evaluating the assessment, Its function in addition to students, it useful for evaluating teacher performance because the teacher must surrender all values and see basic competence that has not been achieved. For daily evaluations, the curriculum submits the technique to the teacher.[13].

\section{c. Teaching - Learning Process}

Furthermore, generally, the teacher's strategic activities are explained based on interviews with three teachers. In improving the quality of learning when viewed from the 7 steps as explained before. Besides that, the teachers should play a role as the spearhead for success in realizing the vision, mission and goals of educational institutions. Teachers who are experienced and have high competence will make the generic strategy of the Islamic School effective one. No matter how good the strategy is at the leadership level or unit level, if the functional level is not active then the end result is not optimal. This means that the objectives of the Islamic school Work Plan and curriculum objectives cannot be achieved if teachers are not able to teach well.

Therefore, teachers should be able to predict student needs now and in the future. Then set goals to meet these needs through learning in Islamic Schools. Because the needs, talents, interests and abilities of students are very diversity, the teacher should be able to determine the appropriate learning strategies between the classes with one another. Teachers can also help students achieve their goals through science.

In choosing a strategy or method of learning, it also adjusted to the characteristics of students and their respective subjects. Such as the selection of inquiry learning strategies that place more emphasis on student independence, expository learning strategies that prioritize the role of the teacher to deliver lessons such as lectures, and demonstrations.

\section{d. Learners}

Learning is a system consisting of several components [14]. To find out how well the learning component is one of them is by digging information from students who are the main customers of education. The results of interviews with two students of Islamic Senior High School 2 Madiun about 5 components of learning consist of: objectives, subject matter, learning methods or strategies, media, evaluation

Based on the interviews with the two students, it can be seen at a glance that the learning system at MAN 2 Madiun is good because students admit that the Islamic School service is in line with their expectations when they used to choose to attend school here. 
Firstly, in terms of goals, students already have their own direction and ideals. And Islamic Schools play a role in helping students achieve their goals. As regarding the subject matter, it also good because the knowledge taught such as religion and other sciences is felt to be in accordance with student expectations although there are some that have not been fulfilled, such as development in the field of ICT. In the learning method or strategy, it usually the average lesson delivered orally, writes on the board and delivers lessons according to basic competence. One of teacher who like and the other also not liked as in the application of $\mathrm{K}-13$, students are confused because they are required to learn independently while the teacher are less directing.

The preferred media is using projectors and practice. It also using games, reading and writing, using a computer when national examination, try out tests based on Android. Evaluation activities at the Islamic School make students more enthusiastic in learning and managing time.

\section{Discussion}

Based on the explanation, the activities carried out by the headmaster of the Islamic school are strategic ones, because they are oriented towards future success; such as preparing students to face the era of industrial revolution 4.0. He should realize the curriculum component of humanistic curriculum model. In this case, students are the main ones and become subjects in education itself. This curriculum emphasizes integrative education between affective and cognitive aspects.

The curriculum concept model used in MAN 2 Madiun is a humanistic one. The main strategy used is competitive marketshare, specific activities developed by the stakeholder to win the market. Those are several model classes; such as bilingual class, an accerated class, vocational class, special skill class programs, as a distinctive strategy for obtaining good input such as the entry requirements of the model class through IQ tests with scores above 130 (above average). That is the action taken by the curriculum practicers be able to do activities better than its competitors.

The formation of religious and nationalist character of students through the habit of reading Quran, praying together and then standing singing the Indonesia Raya national have been performed as nation and religion aims so far. The teacher activities are strategic learning because they are oriented towards future success, such as preparing the success of students towards universities and the world of work in the era of industrial revolution 4.0. The teacher has implemented 7 steps in developing as the Taba said, such as: needs diagnosis, goal of formulation, content of selection, content of organization, selection of learning experience, organization of learning experience, evaluation and how to do it. The learning strategy used consists of inquiry and expository.

The advantages of MAN 2 strategic planning are conducting a model class prepared to win the Olympics. Accelarated class program which allows students to take education faster give an opportunity to several class such as automotive, fashion and electrical fields. The head master supported facilities and infrastructure that are relatively completed that closed relationship with a good Islamic School management because gaining accredited A and ISO 9001: 2008. ,

MAN 2 madiun as stated by students that learning needs students to be more independent turns out to have side effects. That is, if the teacher is too surrendered all to the activity of students, then for some students will feel confused in understanding the lesson. To overcome this, the teacher should choose the right learning method or strategy in guiding and directing 
students according to their preferences. Then regarding the absence of student capacity building activities in the ICT field, it should be immediately organized by the Islamic School. Given in the industrial revolution era 4.0 digital technology is fundamental, competencies needed are not only the ability to operate, but must be able to create new things.

\section{Recommendation and Conclusions}

\section{a. Recommendations}

The writers recommended that the teacher should actively guide students according to their needs and characteristics because of developing ICT, being concentric diversification strategy such as an automotive, fashion, and electricity Islamic school programs. Those lead to be a pioneer Islamic school in the next.

\section{b. Conclusions}

It is necessary for constructing balances among headmaster, vice school, and teachers in implementing several strategies in the form of preparation for the era of the Industrial Revolution 4.0. At this case; i) all stakeholders Islamic School must build the advantage competitive through competitive advantage strategies, ii) vice school principle must improve the quality of learning by using national standards and forming the excellence distinctive competence strategies; namely developing learning programs such as intelligent special, talent special and automotive, and electrical skills programs, iii) all teachers must carry out improving the quality of learning namely compiling learning tools by analyzing needs, setting goals, selecting the content of learning materials, then delivering the subject matter with various strategies such as inquiry and expository, using value integrity and good behavior road to devotion to Allah All-mighty, constructing high-level reasoning.

\section{References}

[1] Suwardana, Hendra. "Revolusi Industri 4. 0 Berbasis Revolusi Mental." JATI UNIK: Jurnal Ilmiah Teknik Dan Manajemen Industri 1, no. 1 (2018): 102. https://doi.org/10.30737/jatiunik.v1i2.117.

[2] Robson, Wendy. Strategic Management and Information Systems. Pearson Higher Ed, 2015.

[3] Nahrowi, Moh. "Perencanaan Strategis Dalam Penyelenggaraan Pendidikan Di Madrasah.” Falasifa: Jurnal Studi Keislaman 8, no. 1 (2017): 9-10.

[4] Heene, Aime, Sebastian Desmidt, Faisal Afiff, and Ismeth Abdullah. Manajemen Strategik Keorganisasian Publik. Bandung: PT Refika Aditama, 2010.Hlm.178

[5] Heene et al. Hlm. 35-36

[6] Undang-Undang, R I. No. 20 Tahun 2003 Tentang Sistem Pendidikan Nasional. Bandung: Citra Umbara, 2003

[7] Sallis, Edward. Total Quality Management in Education. Routledge, 2014. Hlm. 56

[8] Sanjaya, Wina. Teori Dan Praktik Pengembangan Kurikulum Tingkat Satuan Pendidikan (KTSP). Jakarta: Kencana Prenada Media Group, 2008. Hlm. 195

[9] Bryson, John M. Perencanaan Strategis Bagi Organisasi Sosial. Yogyakarta: Prestasi Pustaka Pelajar, 2007.Hlm.207 
[10] Taylor, Steven J, Robert Bogdan, and Marjorie DeVault. Introduction to Qualitative Research Methods: A Guidebook and Resource. New York: John Wiley \& Sons, 2015.Hlm. 5

[11] Biklen, Sari Knopp. Qualitative Research for Education: An Introduction to Theory and Methods. 4th ed. Allyn and Bacon, 2002.Hlm.147

[12] Ary Siswanto, interview, Madiun, $31^{\text {st } O c t o b e r 2018 .}$

[13] Zainal Arifin, interview, Madiun, $15^{\text {th }}$ October2018.

[14] Sanjaya, Wina. Teori Dan Praktik Pengembangan Kurikulum Tingkat Satuan Pendidikan (KTSP). Jakarta: Kencana Prenada Media Group, 2008.Hlm.324 